\title{
Erratum to: Does corruption matter for international entrepreneurship?
}

\author{
Farzana Chowdhury $^{1}$ - Sameeksha Desai ${ }^{1}$. \\ David B. Audretsch ${ }^{1}$ - Maksim Belitski ${ }^{2}$
}

Published online: 12 October 2015

(C) Springer Science+Business Media New York 2015

\section{Erratum to: Int Entrep Manag J DOI 10.1007/s11365-015-0372-5}

A co-author's name was omitted from the original version of this article. The list of authors is now corrected in the author group of this article.

Also, Acknowledgments should read:

This paper is part of Farzana Chowdhury's dissertation. I would like to thank Siri Terjesen, Patricia McDougal, Denvil Duncan, Erik Stam for their comments on the earlier version of the paper.

The online version of the original article can be found at http://dx.doi.org/10.1007/s11365-015-0372-5.

Farzana Chowdhury

fchowdhu@indiana.edu

David B. Audretsch

daudrets@indiana.edu

Maksim Belitski

m.belitski@reading.ac.uk

1 Indiana University, Bloomington, IN, USA

2 Henley Business School, University of Reading, Reading, UK 